\title{
Agarose-Based Biomaterials: Opportunities and Challenges in Cartilage Tissue Engineering
}

\author{
Mohammad Amin Salati ${ }^{1,+}$, Javad Khazai ${ }^{1,+}+\mathbb{D}$, Amir Mohammad Tahmuri ${ }^{1}$, Ali Samadi ${ }^{1}(\mathbb{D}$, \\ Ali Taghizadeh ${ }^{2}$, Mohsen Taghizadeh ${ }^{2}$, Payam Zarrintaj ${ }^{3, *} \mathbb{0}$, Josh D. Ramsey ${ }^{3}$, \\ Sajjad Habibzadeh ${ }^{4}$, Farzad Seidi ${ }^{5}$, Mohammad Reza Saeb ${ }^{6, *}$ (D) and Masoud Mozafari ${ }^{7, *}$ (D) \\ 1 Polymer Engineering Department, Faculty of Engineering, Urmia University, Urmia 5756151818, Iran; \\ salati.mohammadamin1999@gmail.com (M.A.S.); jkhazaei78@gmail.com (J.K.); \\ pmbltzr@gmail.com (A.M.T.); ali.samadi2@gmail.com (A.S.) \\ 2 Center of Excellence in Electrochemistry, School of Chemistry, College of Science, University of Tehran, \\ Tehran 11155-4563, Iran; clarion.payam@gmail.com (A.T.); m.taghizadeh@gmail.com (M.T.) \\ 3 School of Chemical Engineering, Oklahoma State University, 420 Engineering North, Stillwater, OK 74078, \\ USA; josh.ramsey@okstate.edu \\ 4 Department of Chemical Engineering, Amirkabir University of Technology (Tehran Polytechnic), \\ Tehran 1591639675, Iran; sajadhabibzadeh@gmail.com \\ 5 Provincial Key Lab of Pulp and Paper Science and Technology and Joint International Research Lab of \\ Lignocellulosic Functional Materials, Nanjing Forestry University, Nanjing 210037, China; \\ f_seidi@njfu.edu.cn \\ 6 Department of Resin and Additives, Institute for Color Science and Technology, \\ Tehran P.O. Box 16765-654, Iran \\ 7 Department of Tissue Engineering and Regenerative Medicine, Faculty of Advanced Technologies in \\ Medicine, Iran University of Medical Sciences, Tehran 144961-4535, Iran \\ * Correspondence: payam.zarrintaj@gmail.com (P.Z.); saeb-mr@icrc.ac.ir (M.R.S.); \\ mozafari.masoud@gmail.com (M.M.) \\ + These authors contributed equally to this work.
}

Received: 29 March 2020; Accepted: 2 May 2020; Published: 18 May 2020

\begin{abstract}
The lack of adequate blood/lymphatic vessels as well as low-potential articular cartilage regeneration underlines the necessity to search for alternative biomaterials. Owing to their unique features, such as reversible thermogelling behavior and tissue-like mechanical behavior, agarose-based biomaterials have played a key role in cartilage tissue repair. Accordingly, the need for fabricating novel highly efficient injectable agarose-based biomaterials as hydrogels for restoration of injured cartilage tissue has been recognized. In this review, the resources and conspicuous properties of the agarose-based biomaterials were reviewed. First, different types of signals together with their functionalities in the maintenance of cartilage homeostasis were explained. Then, various cellular signaling pathways and their significant role in cartilage tissue engineering were overviewed. Next, the molecular structure and its gelling behavior have been discussed. Eventually, the latest advancements, the lingering challenges, and future ahead of agarose derivatives from the cartilage regeneration perspective have been discussed.
\end{abstract}

Keywords: agarose; biomaterials; hydrogels; cartilage; tissue engineering; regenerative medicine

\section{Introduction}

Millions of people in the world are suffering from articular cartilage diseases (ACD) and its side effects, such as anterior cruciate ligament (ACL) and osteochondral defects (OCD). It is expected that OCD will be the principal reason for incapacity in the next decades, with $35 \%$ of the population affected. 
The occurrence of OCD depends on age, gender, and environmental conditions. Although treating the defects using surgeries is promising, cartilage regeneration remains as a post-surgery complication because of its structural complexity and low metabolic performance [1,2]. Furthermore, the long-term healing period of internal articular cartilage demands new strategies for repairing cartilage without surgery [3].

Tissue engineering is an interdisciplinary branch of science for designing and implementing novel treatment strategies based on natural/synthetic materials along with cell and therapeutic agents to treat the injured tissues [4-6]. Tissue engineering has opened a promising path to regenerate the cartilage using modified natural/synthetic biomacromolecules. The first step in material selection for tissue engineering is the tissue recapitulation by the selected scaffold [7-9]. Therefore, the mechanical behavior of the intended material should match with its nearby cartilage in order to keep its function $[10,11]$. Biopolymers such as chitosan [12,13], alginate [14,15], gelatin [16,17], and agarose [18] have been widely used for tissue engineering $[19,20]$ because of their proper biocompatibility, controllable degradability, and tissue-mimicking performance.

Agarose has been used vastly in biomedical applications because of its controlled self-gelling properties, water-solubility, adjustable mechanical properties, and non-immunogenic properties. Agarose, based on its stiffness and functional groups, can support cellular adhesion, proliferation, and activity. Agarose has adjustable water adsorption capacity, which provides the cells with a suitable microenvironment for cellular activity [21]. Agarose-based hydrogels have considerably been utilized in the investigation of mechanical load reaction for chondrocytes and mesenchymal stem cells (MSCs) [22]. Agarose has acquired a wide range of applications such as drug delivery [23,24], cancer therapy [25,26], tissue engineering and regenerative medicine [27-30], and disease diagnosis, controlling, and treatment [31-33]. It has been utilized in various tissue engineering applications, including the neural system [34], bone formation [35], cardiac regeneration, wound healing, and attachment to tissues such as skin [36], brain [37], and cornea. The properties of agarose are tunable by concentration, functionalization, and blending to mimic the desired tissue performance. Figure 1 exhibits the agarose gel performance for various tissues and cells.

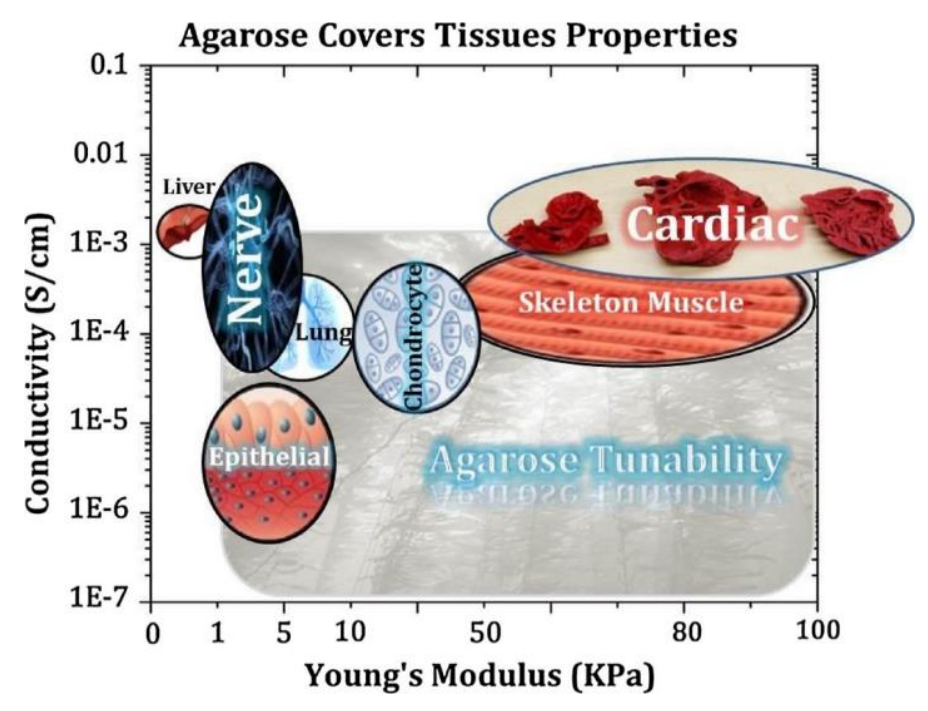

Figure 1. Adjustable features of agarose can result in flexible characteristics similar to cells and tissues. Here, the conductivity and Young's modulus of agarose-based biomaterials are patterned. Reprinted with permission from [18].

\section{Cartilage Types, Properties, and Formation}

Cartilage is a smooth elastic tissue, which covers the end of bones at the joints and protects them against mechanical stresses. There are three types of cartilage: articular (hyaline), fibrous, and elastic $[38,39]$. Heterotypic collagen II/IX/XI fibrils and proteoglycan-glycosaminoglycan networks 
of aggrecan and hyaluronan are the dominant structures of the cartilage extracellular matrix (ECM). Hyaline is an elastic, flexible, and wear-resistant tissue that is accessible inside the joint to carry and disrupt the weight. The cartilages of the ear, larynx, and epiglottis are more elastic than the hyaline. Fibrocartilage as inexorable cartilage is available in the knee and between the vertebrae [40].

Low-speed regeneration of cartilage tissue is chiefly because of a lack of blood vessels and nerves. This phenomenon may lead to rheumatoid arthritis, inflammatory disease, and deterioration of the joints, causing pain for a long time. Collagen (type II), hyaluronan, and dormant sulfate are the major components of the cartilage tissue ECM. Cartilage damage is accompanied by ECM degradation and mobilization of joint chondrocytes from other areas with decreased infiltration and vascularization of inflammatory cells. Figure 2 shows the cartilage structure [41].

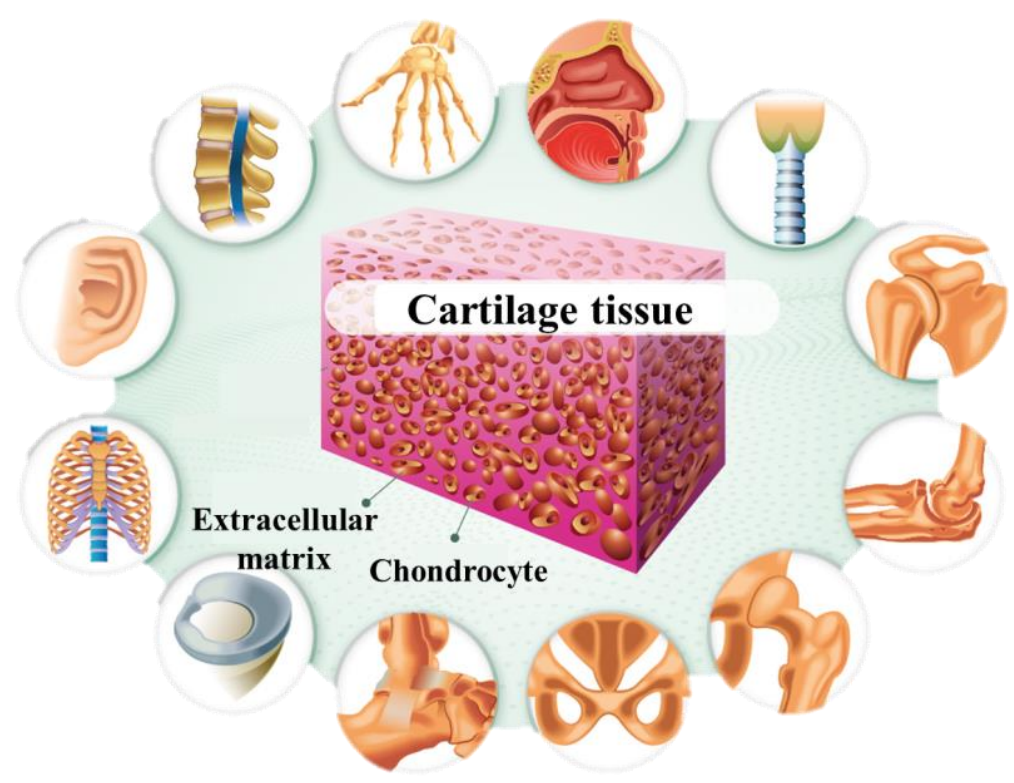

Figure 2. Schematic of the cartilage tissue structure. (a) Collagen (type II) and chondrocytes are two major components of cartilage tissue, the application of cartilage tissue in different parts of the human body (reproduced with permission from [42]).

Different biomaterials can be utilized in repairing the cartilage; however, we should point out that the signal paths and biological signs involved in the cartilage are activated so that we can begin to interact and reconstruct the muscles. Chondrogenesis is a process by which various cellular signals are sent in the regulation of cartilage formation [43]. Multiple factors have been announced for cartilage repair, such as transforming growth factor $\beta$ (TGF $\beta)$, parathyroid hormone-related protein (PTHrP), Wnts, Indian hedgehog, thyroid hormone, bone morphogenetic protein (BMP) superfamily, platelet-derived factors (PDGFs), insulin-like growth factors (IGFs), fibroblast growth factors (FGFs), and different vitamins (Table 1) [44]. TGF $\beta$ s play a vital role in regulating the proliferation/differentiation of chondrocytes. TGF $\beta$ stimulates the RY-box expression causing the formation of collagen type II and aggrecan in the early condensation phase of MSCs [45]. Wnt and $\beta$-catenin-dependent signaling pathways possess vital functions in developing chondrocytes (Table 2). The $\beta$-catenin-dependent stimulates endochondral ossification and axial growth [44]. 
Table 1. The different types of signal plus their functionalities and crucial roles in the maintenance of cartilage homeostasis [43].

\begin{tabular}{ll}
\hline Type of Signal & \multicolumn{1}{c}{ Role (Duty) } \\
\hline TGF- $\beta$ & $\begin{array}{l}\text { Regulates the proliferation/differentiation of chondrocytes, and stimulates the } \\
\text { RY-box expression }\end{array}$ \\
\hline BMP & $\begin{array}{l}\text { Plays an important role in various stages of skeletal growth, and the commitment of } \\
\text { mesenchymal cells to the lines of chondrocytes in the induction of proliferation and cell } \\
\text { maturation in the growth and formation of the joints and bones }\end{array}$ \\
\hline IGF & Develops cartilage and reproduces chondrocytes on the growth plate \\
\hline FGF & Develops vital organs \\
\hline
\end{tabular}

Table 2. Various cellular signaling pathways and their significant role in cartilage tissue engineering.

\begin{tabular}{ll}
\hline Signaling Pathway & \multicolumn{1}{c}{ Role (Duty) } \\
\hline SMAD & $\begin{array}{l}\text { Expresses pre-hypertrophic and proliferative and hypertrophic chondrocytes } \\
\text { in all regions of the cartilage }\end{array}$ \\
\hline b-catenin-dependent & $\begin{array}{l}\text { Stimulates bone growth in axial growth, and induces endochondral } \\
\text { ossification and axial growth }\end{array}$ \\
\hline Non-canonical WNT & Creates growth pillars by chondrocytes \\
\hline
\end{tabular}

\section{Agarose Properties}

Extraction of agar from the algae source [46], Ahnfeltia plicata [47], Gelidium amansii [48], and Eucheuma [49], using chemical treatment ( $\mathrm{NaOH}$ [50], ionic liquids [51], $\mathrm{Na}_{2} \mathrm{CO}_{3}$ [50]), is the main method conducted, as illustrated by the steps detailed in Figure 3. Agar was utilized as a source of agarose extraction, in the same way as has been explained above [46,48] (see Figure 1).

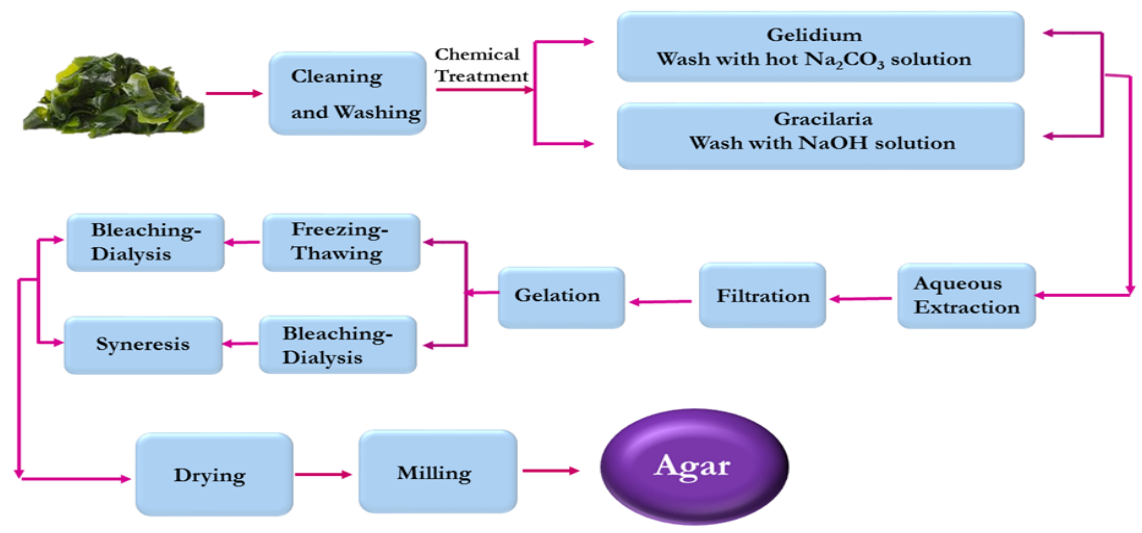

(a)

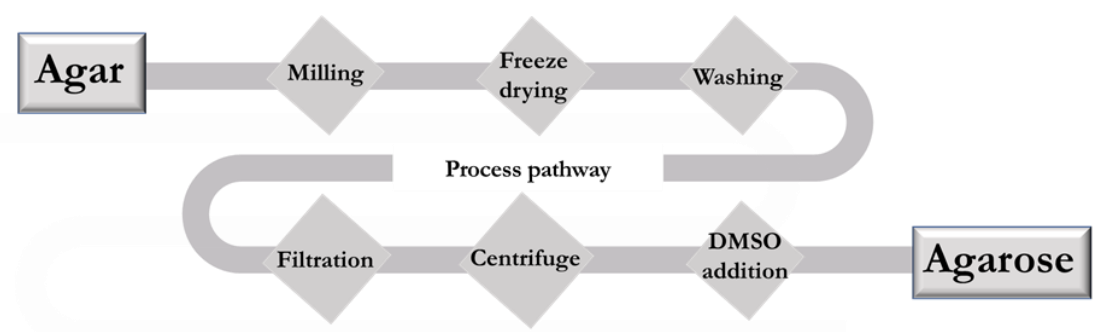

(b)

Figure 3. Schematic illustration of extraction route for the production of (a) agar from algae through a chemical treatment and physical filtration for $(\mathbf{b})$ agarose from agar source using DMSO solution. 
The molecular weight of agarose is almost $120,000 \mathrm{~g} / \mathrm{mol}(12 \mathrm{kDa})$. It is in the form of a white powder that dissolves in hot water to form a gel when cooled to below an upper critical solution temperature (UCST) [18]. Furthermore, agarose dissolves in several organic solvents such as dimethyl sulfoxide (DMSO), dimethylformamide (DMF), formamide (FA), N-methylformamide (MFA), and 1-Butyl-3-methylimidazolium chloride (BmimCl) [52,53]. Agarose is a part of the agar that is obtained by separating the agar-peptide. Various factors such as molecular weight, concentration, and lateral groups significantly affect the melting and gelling temperature [19,52,54]. Overall, $1.5 \%$ of each agarose type, such as types II, VII, and IX-A, have different gelling and melting temperatures, at $26,26-30$, and $17^{\circ} \mathrm{C}$, respectively [55].

The agarose gelation process is divided into three stages: induction, gelation, and quasi-equilibrium [56,57]. The mechanism of gelation is usually characterized using rheological experiments [56], and it includes nucleation and growth of nuclei. Several agarose nuclei are formed in the first step followed by the growing of nuclei, which gradually form agarose-rich networks (Figure 4). In agarose, the formation of gel is related to the agarose molecule twisting linked to the transplantation of hydrogen and electrostatic penetration [58]. In the end, it is essential to note that the concentration of the agarose gel determines its permeability [59].

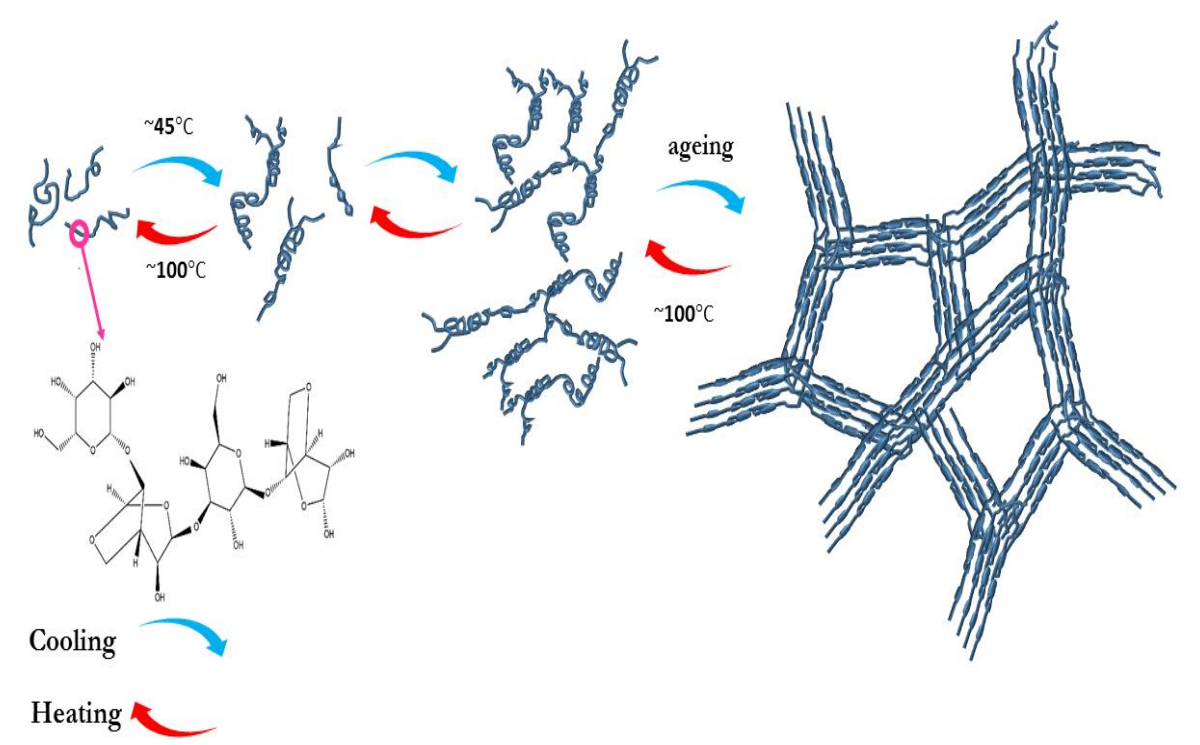

Figure 4. The molecular structure of agarose and schematic of its gelling process (reprinted from [21]).

A big challenge in cartilage tissue engineering is to achieve mechanical properties similar to cartilage itself [60]. Agarose hydrogels can be an appropriate selection for cartilage tissue engineering because of the adjustable mechanical properties, swelling ratio, and therapeutic factors. The mechanical properties of agarose can be tuned by altering the concentration. For instance, the elastic modulus for different concentrations of agarose with compression membranes has been calculated from $0.5 \%, 1.0 \%$, $2.5 \%$, and $5.0 \%$ of the agarose gel as $5.3,38,254,929 \mathrm{KPa}$, respectively [61].

Comparing Young's modulus of different body organs with agarose is of particular interest in tissue engineering (Figure 1), but on the other hand, Young's modulus of agarose is less than $0.5 \mathrm{MPa}[62,63]$, indicating that agarose has high-pressure tolerance compared to natural tissues. Young's moduli for bone, cartilage, nerve, cardiac, skeletal muscle, endothelium, liver, and lung are in the range of 1-20 GPa [64], 10-20 KPa [65], 0.1-2 KPa [66], 30-400 KPa [67], 20-100 KPa [68], 1-7 KPa [69], 0.3-0.8 KPa [70], and 1-5 KPa, respectively [70].

The mechanical behavior of agarose is comparable to articular cartilage upon static or dynamic loading [71,72]. Since cartilage and agarose are both hydrated materials, they exhibit strain-dependent hydraulic permeability, which means that resistance to water transportation through the hydrogel increases with the increase of applied deformation (and the collapse of the pores) [73]. 


\section{Agarose in Cartilage Regeneration}

Cartilage exhibits arduous regeneration because of its avascular nature. Therefore, cartilogenesis is known as a challenging field in regenerative medicine and tissue engineering. Cartilage as a microenvironment possesses a hypoxic condition that facilitates the differentiation of MSCs to chondrogenesis rather than osteogenesis [74]. The degree of success in cartilage tissue engineering is pertinent to the cells, growth factors, and biomaterials. Moreover, the age and size of the injured section impacts the regeneration process. Biomaterials in cartilage repair, along with proper biocompatibility and biodegradability, should offer a suitable milieu for proliferation, differentiation, and migration of chondrocytes. Guaccio et al. revealed that cartilage growth is usually diminished by the problem of inadequate oxygen/nutrient source to cultured cells in 3D platforms. It was understood that oxygen utilization level is two times greater in agarose compared to collagen, indicating that the nature of the material greatly impacts cell metabolic performance [75]. Applying an agarose hydrogel-based scaffold for cartilage regeneration stabilized the chondrocyte phenotype and enhanced the proteoglycan and glycosaminoglycans precipitation [76]. Cigan et al. encapsulated the human chondrocyte in an agarose scaffold for cartilage regeneration. Engineered cartilaginous structure substantially appeared like native human cartilage, and possessed compressive Young's and dynamic moduli of about 250 and $950 \mathrm{kPa}$, respectively. Moreover, it was composed of $5.7 \%(\mathrm{w} / \mathrm{w})$ of glycosaminoglycans and $1.5 \%(\mathrm{w} / \mathrm{w})$ collagen [76]. Implantation of autologous chondrocyte is a recognized technique for symptomatic articular flaws. Selmi et al. used agarose-based hydrogel to enhance cell phenotypic constancy and improve surgical management. Overall, seventeen patients were used as clinical trials and were surveyed for two years. Clinically, all the patients were treated substantially. Patients with defects more than $3 \mathrm{~cm}^{2}$ were improved drastically compared to those with smaller ones. Moreover, in eight cases, dominant hyaline cartilage-like repair tissue was detected [77]. Kock et al. studied the agarose concentration on chondrocyte behavior [19]. Matrix formation around the chondrocyte was affected by agarose concentration. A low concentration of agarose facilitated the proteoglycans diffusion. Agarose with $1 \%$ concentration resulted in collagen II deposition in a radial manner, while $2 \%$ and $3 \%$ agarose concentrations resulted in a dense layer of collagen formation around the cell. The $1 \%$ agarose contained more proteoglycans compared to those having $2 \%$ and $3 \%$ agarose. It was deduced that the agarose concentration reduction caused more nutrient diffusion and enhancement of matrix deposition like collagen fibril. At lower concentrations of agarose, a uniform matrix was developed that increased the modulus at equilibrium state. Therefore, low concentration agarose increased the deposition of the extracellular matrix, which improved the mechanical properties [60]. In Table 3, the mechanical properties, the concentrations and the methods of applications of agarose-based biomaterials are presented. 
Table 3. A brief view at the mechanical properties, concentrations, and the methods of applications of agarose-based biomaterials in biomedical applications.

\begin{tabular}{|c|c|c|c|c|c|}
\hline Material & Concentration \% & $\begin{array}{c}\text { Mechanical } \\
\text { Properties (KPa) }\end{array}$ & Methods & Action & Ref. \\
\hline Agarose & 1 & 10 & \multirow{13}{*}{$\begin{array}{l}\text { The effect of TGF-b3 was compared to the } \\
\text { fatal bovine serum. Mechanical properties } \\
\text { were assessed at day } 42 \text {. }\end{array}$} & \multirow{13}{*}{$\begin{array}{l}\text { Low-concentration agarose stimulates the } \\
\text { formation of more Homogeneous } \\
\text { ECM distribution. } \\
\text { The presence of TGF-b3 is also beneficial } \\
\text { because it stimulates the distribution of } \\
\text { matrix components. } \\
\text { Both stimuli result in constructs with } \\
\text { improved mechanical properties }\end{array}$} & \multirow{13}{*}{ [60] } \\
\hline Agarose & 2 & 16 & & & \\
\hline Agarose & 3 & 35 & & & \\
\hline Agarose-FBS & 1 & 15 & & & \\
\hline Agarose-FBS & 2 & 25 & & & \\
\hline Agarose-FBS & 3 & 40 & & & \\
\hline Agarose-TGF & 1 & 40 & & & \\
\hline Agarose-TGF & 2 & 45 & & & \\
\hline Agarose-TGF & 3 & 50 & & & \\
\hline Agarose-TGF & 0.25 & 40 & & & \\
\hline Agarose-TGF & 0.5 & 27 & & & \\
\hline Agarose-TGF & 1 & 34 & & & \\
\hline Agarose-TGF & 1 disc & 38 & & & \\
\hline \multirow[t]{7}{*}{ Agarose } & 2 & 1.547 & \multirow{7}{*}{ Gel } & \multirow{7}{*}{$\begin{array}{l}\text { Both the volume fraction of water and } \\
\text { hydraulic permeability decreased with } \\
\text { increasing agarose gel concentration. } \\
\text { Permeability was dependent on hydrogel } \\
\text { and cartilage deformation }\end{array}$} & \multirow{7}{*}{ [78] } \\
\hline & 2.5 & 4.237 & & & \\
\hline & 3 & 10.03 & & & \\
\hline & 4 & 10.55 & & & \\
\hline & 6 & 33.16 & & & \\
\hline & 10 & 82.34 & & & \\
\hline & 14.8 & 333.4 & & & \\
\hline \multirow[t]{3}{*}{ PRP-agarose } & 7 days & 32 & \multirow{3}{*}{$\begin{array}{l}\text { Porcine chondrocytes were seeded in agarose } \\
\text { gel and platelet-rich plasma-agarose gel. }\end{array}$} & \multirow{3}{*}{$\begin{array}{l}\text { The hydrogel possesses a proper } \\
\text { microenvironment for chondrocyte growth, } \\
\text { proliferation and matrix formation }\end{array}$} & \multirow{3}{*}{ [79] } \\
\hline & 14 days & 50 & & & \\
\hline & 28 days & 75 & & & \\
\hline
\end{tabular}


Table 3. Cont.

\begin{tabular}{|c|c|c|c|c|c|}
\hline Material & Concentration \% & $\begin{array}{c}\text { Mechanical } \\
\text { Properties (KPa) }\end{array}$ & Methods & Action & Ref. \\
\hline $\begin{array}{l}\text { AG-BM Strong } \\
\text { modulus }\end{array}$ & & 13.20 & \multirow{3}{*}{ Blended hydrogels } & $\begin{array}{l}\text { The degradation capability of blended } \\
\text { hydrogel circumvents the drawbacks of the }\end{array}$ & \multirow{3}{*}{ [53] } \\
\hline $\begin{array}{l}\text { AG-BM Loss } \\
\text { modulus }\end{array}$ & & \multirow[t]{2}{*}{4.96} & & $\begin{array}{l}\text { otherwise non-degradable pure agarose } \\
\text { The hydrogels with non-mulberry SF blends } \\
\text { showed larger pore size as compared to the }\end{array}$ & \\
\hline & & & & $\begin{array}{l}\text { mulberry blend hydrogels. } \\
\text { The rheological studies revealed elasticity of } \\
\text { the blended hydrogels had a yield point at a } \\
\text { higher amplitude strain as compared to } \\
\text { pure agarose }\end{array}$ & \\
\hline & & & rolled emulsion techr & & [80] \\
\hline
\end{tabular}


Agarose blending enhances its cellular activity and regeneration. Singah et al. blended the agarose with silk to regenerate the cartilage [53]. The results indicated that the silk/agarose scaffold increased sulfated glycosaminoglycans (sGAG) and collagen deposition as a signature of the preservation of chondrogenic phenotype. Moreover, it was revealed that up-regulation of cartilage-specific aggrecan, sox-9 ( 1.5-fold) and collagen type II ( 2-fold) marker genes $(p \leq 0.01)$ in blended hydrogels collagen and fibronectin colocalization was a suitable method to improve the agarose microenvironment for chondrocytes culture. Furthermore, the connection between collagen or fibronectin with chondrocytes and the connection between chondrocytes with living cartilage resulted in an increasing matrix and cohesion of matrix-matrix that improved cartilage regeneration [70]. Platelet-rich plasma (PRP) is the source of known growth factors. Thus, a scaffold was made using a platelet-rich plasma-agarose gel, and the results showed that PRP-agarose gel was extensively uniform in the structure with high-level concentration, as a signal of an increased amount of collagen type -I mRNA expression in the structure [79]. Dekosky et al. synthesized an interpenetrating network of hydrogels based on agarose/Poly(ethylene Glycol) to encapsulate cells for cartilage regeneration [81]. Espinosa et al. synthesized a magnetic fibrin-agarose hydrogel for cartilage regeneration. It was noticed that magnetic particles increased the mechanical features of fibrin-agarose hydrogels. Moreover, chondrocytes seeded in magnetic substrate expressed type II collagen. Magnetic hydrogels demonstrated a high ability for hyaline cartilage-like tissue engineering [82].

Osteochondral flaws or cartilaginous damage can be treated using allogeneic cartilage transplantation. Immune rejection is a challenging issue with grafting, though. Yang et al. used basic fibroblast growth factor (BFGF) and agarose to regenerate the cartilage with minimum immunological stimulation. Treated with BFGF, agarose and allogeneic cartilage resembled the autologous one. The monocytes level in allografts was at its maximum level in the spleen and blood; the CD4+ T cells number in the allogeneic group was greater than others. Allogeneic cartilage transplantation stimulates acute immune rejection, which deals with the authenticity of the implant. The combination of BFGF and agarose simplifies the aim of immune privilege and enhances the allograft tissues' performance (Figure 5) [83].
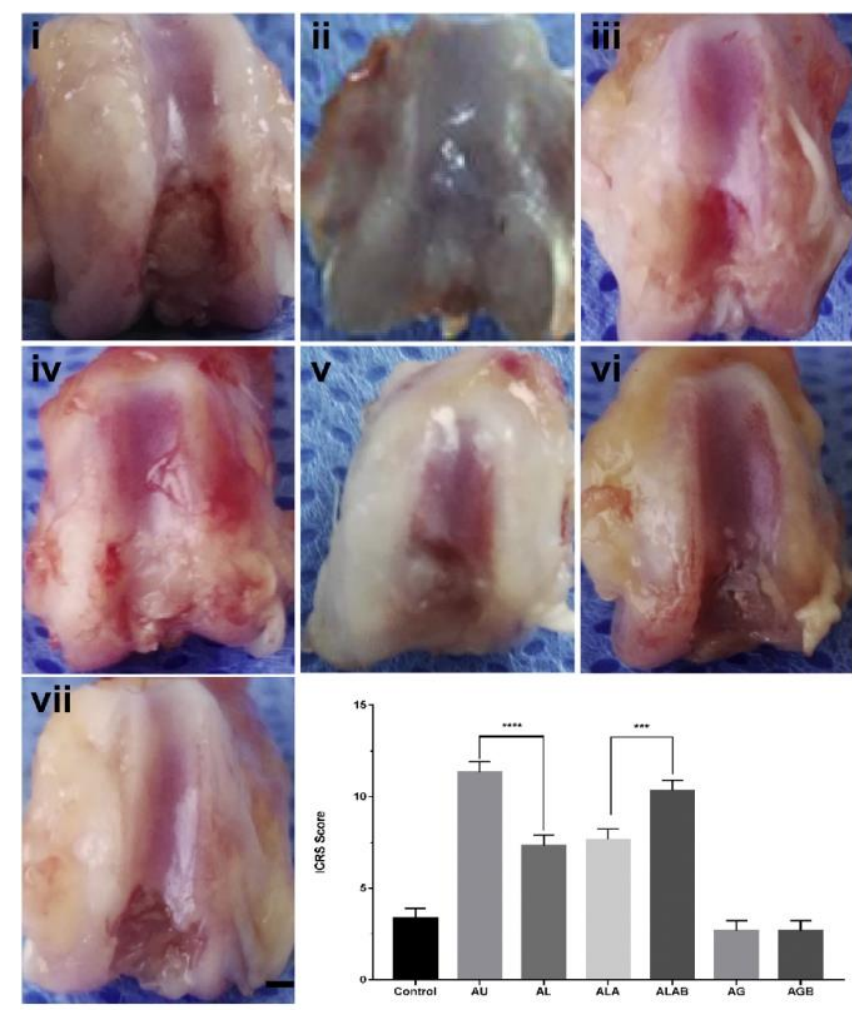

Figure 5. Cont. 


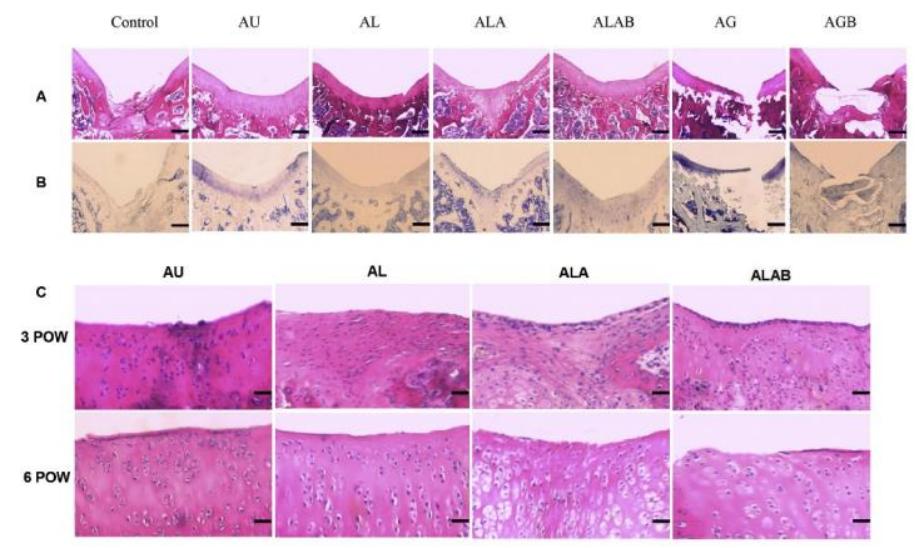

Figure 5. cartilage injury after transplantation of different groups: (i) nontransplant control, (ii) autologous articular cartilage (AU), (iii) allogeneic (same species, different rat) articular cartilage (AL), (iv) allogeneic articular cartilage replacing agarose gel (ALA), (v) allogeneic articular cartilage replacing agarose gel with bFGF (ALAB), (vi) agarose gel (AG), and (vii) agarose gel with bFGF (AGB). The cartilage restoration evaluation was drastically greater in the AU group than that in the AL group, as was the ALAB group compared with the ALA group. Assessment of histological data after transplantation. (A,B) Nontransplant control: amorphous reparative tissue filling the subchondral region. AU: intensive staining covering the defect. AL: the intensity of staining in the regenerated region was less than that of AU and ALAB. ALA: partly positive cartilage organization in the area. ALAB: amounts of cartilage-like tissue restored in the full-thickness defect. AG and AGB showed the agarose gel occupied the space and hindered the reconstructive process. (C) Histological findings in knee cartilage in the transplantation site at postoperative week (POW) 3 and POW 6 (hematoxylin and eosin). At POWs 3 and 6, the ALAB and AU groups showed no obvious evidence of rejection. In the other two groups, chondrocytes with small, condensed nuclei were visible at each time point. Scale bar is $50 \mu \mathrm{m}$ for all images (Reprinted with permission form [83]).

\section{Future Perspective and Concluding Remarks}

Agarose is a wonderful biopolymer extracted from agar possessing extraordinary properties such as excellent porous structure with interconnected pores to ease the nutrient, oxygen permeation, and waste exchanges, the desired biodegradability and biocompatibility, a high ability to mimic human tissue, perfect cell/matrix interaction, and great hydrophilicity and elasticity. Such promising characteristics allow the migration/proliferation of cells, and a wide range of Young's modulus associated with ionic conductivity makes agarose a supreme applicant for the regeneration of many human organs. The biggest advantage of agarose hydrogels is the encapsulation of chondrocytes and cartilage cells at a cellular level which enables 3D cultures missing the loss of phenotype or morphology. Cartilage tissue due to the absence of ample blood vessels and a low amount of stem cells requires a suitable environment like hydrogels for filling the defected part when it gets damaged and makes a human-tissue-like environment to help the regeneration process. Agarose and its composites presented a conspicuous role in the regeneration of cartilage tissue. Distinctive characteristics of agarose-based hydrogels such as excellent mechanical properties which can mimic the real hard/soft tissue with high agreement, non-immunological, great biocompatibility, nontoxicity, and high cell/matrix interaction have emphasized their application in cartilage repair research. The concerns and studies to fabricate the best compatible agarose-based hydrogels for engineered tissue cartilage applications and the development of complexes and interlinked types of agarose hydrogels have acquired more currency amongst scientists. However, these hydrogels still need more advanced assessments in clinics and real-world applications. Consequently, an additional organized attempt is crucial to filling the current gap in cartilage repair that involves details of the main elements of agarose-based hydrogels. Moreover, thanks to novel techniques such as bioprinting, the novel and precise 3D-printed scaffold can be fabricated for cartilage regeneration. 
Author Contributions: Conceptualization, P.Z. \& M.R.S.; methodology, P.Z.; formal analysis, M.A.S., J.K. \& A.M.T.; investigation, A.S., A.T. \& M.T.; writing-original draft preparation, M.A.S., J.K. \& A.M.T.; writing-review and editing, J.D.R., S.H. \& F.S.; supervision, M.R.S. \& M.M.; All authors have read and agreed to the published version of the manuscript.

Funding: This research received no external funding.

Conflicts of Interest: The authors declare no conflict of interest.

\section{References}

1. Robbins, S.; Abram, F.; Boily, M.; Pelletier, J.-P.; Martel-Pelletier, J. Relationship between alignment and cartilage thickness in patients with non-traumatic and post-traumatic knee osteoarthritis. Osteoarthr. Cartil. 2019, 27, 630-637. [CrossRef]

2. Farokhi, M.; Mottaghitalab, F.; Fatahi, Y.; Saeb, M.R.; Zarrintaj, P.; Kundu, S.C.; Khademhosseini, A.J. Silk fibroin scaffolds for common cartilage injuries: Possibilities for future clinical applications. Eur. Polym. J. 2019, 115, 251-267. [CrossRef]

3. Orman, O.; Ozturk, K.; Baydar, M.; Guneren, E.; Taslidere, E.; Orman, M.; Ozel, O. Influence of articular arthroscopy-like washout on fracture healing of intra-articular fractures. Anim. Exp. 2020, 3, 18-29. [CrossRef]

4. Khalili, R.; Zarrintaj, P.; Jafari, S.H.; Vahabi, H.; Saeb, M.R. Electroactive poly (p-phenylene sulfide)/r-Graphene Oxide/Chitosan as a novel potential candidate for tissue engineering. Int. J. Biol. Macromol. 2020, 154, 18-24. [CrossRef] [PubMed]

5. Samadi, A.; Hasanzadeh, R.; Azdast, T.; Abdollahi, H.; Zarrintaj, P.; Saeb, M.R. Piezoelectric Performance of Microcellular Polypropylene Foams Fabricated Using Foam Injection Molding as a Potential Scaffold for Bone Tissue Engineering. J. Macromol. Sci. Part B 2020, 1-14. [CrossRef]

6. Saberi, A.; Jabbari, F.; Zarrintaj, P.; Saeb, M.R.; Mozafari, M. Electrically Conductive Materials: Opportunities and Challenges in Tissue Engineering. Biomolecules 2019, 9, 448. [CrossRef]

7. Zarrintaj, P.; Saeb, M.R.; Ramakrishna, S.; Mozafari, M. Biomaterials selection for neuroprosthetics. Curr. Opin. Biomed. Eng. 2018, 6, 99-109. [CrossRef]

8. Zarrintaj, P.; Saeb, M.R.; Jafari, S.H.; Mozafari, M. Application of compatibilized polymer blends in biomedical fields. In Compatibilization of Polymer Blends; Elsevier: Amsterdam, The Netherlands, 2020; pp. 511-537.

9. Zarrintaj, P.; Bakhshandeh, B.; Saeb, M.R.; Sefat, F.; Rezaeian, I.; Ganjali, M.R.; Ramakrishna, S.; Mozafari, M. Oligoaniline-based conductive biomaterials for tissue engineering. Acta Biomater. 2018, 72, 16-34. [CrossRef]

10. García-Martínez, L.; Campos, F.; Godoy-Guzmán, C.; Sánchez-Quevedo, M.D.; Garzón, I.; Alaminos, M.; Campos, A.; Carriel, V. Encapsulation of human elastic cartilage-derived chondrocytes in nanostructured fibrin-agarose hydrogels. Histochem. Cell Biol. 2017, 147, 83-95. [CrossRef]

11. Mohebbi, S.; Nezhad, M.N.; Zarrintaj, P.; Jafari, S.H.; Gholizadeh, S.S.; Saeb, M.R.; Mozafari, M. Chitosan in biomedical engineering: A critical review. Curr. Stem Cell Res. Ther. 2019, 14, 93-116. [CrossRef]

12. Bagheri, B.; Zarrintaj, P.; Samadi, A.; Zarrintaj, R.; Ganjali, M.R.; Saeb, M.R.; Mozafari, M.; Park, O.O.; Kim, Y.-C. Tissue engineering with electrospun electro-responsive chitosan-aniline oligomer/polyvinyl alcohol. Int. J. Biol. Macromol. 2020, 147, 160-169. [CrossRef] [PubMed]

13. Bagheri, B.; Zarrintaj, P.; Surwase, S.S.; Baheiraei, N.; Saeb, M.R.; Mozafari, M.; Kim, Y.-C.; Park, O.O. Self-gelling electroactive hydrogels based on chitosan-aniline oligomers/agarose for neural tissue engineering with on-demand drug release. Colloids Surf. B Biointerfaces 2019, 184, 110549. [CrossRef] [PubMed]

14. Alizadeh, R.; Zarrintaj, P.; Kamrava, S.K.; Bagher, Z.; Farhadi, M.; Heidari, F.; Komeili, A.; Gutiérrez, T.J.; Saeb, M.R. Conductive hydrogels based on agarose/alginate/chitosan for neural disorder therapy. Carbohydr. Polym. 2019, 224, 115161. [CrossRef] [PubMed]

15. Atoufi, Z.; Zarrintaj, P.; Motlagh, G.H.; Amiri, A.; Bagher, Z.; Kamrava, S.K. A novel bio electro active alginate-aniline tetramer/agarose scaffold for tissue engineering: Synthesis, characterization, drug release and cell culture study. Polym. Ed. 2017, 28, 1617-1638. [CrossRef]

16. Bagher, Z.; Atoufi, Z.; Alizadeh, R.; Farhadi, M.; Zarrintaj, P.; Moroni, L.; Setayeshmehr, M.; Komeili, A.; Kamrava, S.K. Conductive hydrogel based on chitosan-aniline pentamer/gelatin/agarose significantly promoted motor neuron-like cells differentiation of human olfactory ecto-mesenchymal stem cells. Mater. Sci. Eng. C 2019, 101, 243-253. [CrossRef] 
17. Zarrintaj, P.; Urbanska, A.M.; Gholizadeh, S.S.; Goodarzi, V.; Saeb, M.R.; Mozafari, M. A facile route to the synthesis of anilinic electroactive colloidal hydrogels for neural tissue engineering applications. J. Colloid Interface Sci. 2018, 516, 57-66. [CrossRef]

18. Zarrintaj, P.; Manouchehri, S.; Ahmadi, Z.; Saeb, M.R.; Urbanska, A.M.; Kaplan, D.L.; Mozafari, M. Agarose-based biomaterials for tissue engineering. Carbohydr. Polym. 2018, 187, 66-84. [CrossRef]

19. Kock, L.M.; Van Donkelaar, C.C.; Ito, K. Agarose concentration and TGF-B3 supplementation influence matrix deposition in engineered cartilage constructs. In Proceedings of the ASME 2011 Summer Bioengineering Conference, Farmington, PA, USA, 22-25 June 2011; pp. 879-880.

20. Zarrintaj, P.; Moghaddam, A.S.; Manouchehri, S.; Atoufi, Z.; Amiri, A.; Amirkhani, M.A.; Nilforoushzadeh, M.A.; Saeb, M.R.; Hamblin, M.R.; Mozafari, M. Can regenerative medicine and nanotechnology combine to heal wounds? The search for the ideal wound dressing. Nanomedicine 2017, 12, 2403-2422. [CrossRef]

21. Zarrintaj, P.; Bakhshandeh, B.; Rezaeian, I.; Heshmatian, B.; Ganjali, M.R. A novel electroactive agarose-aniline pentamer platform as a potential candidate for neural tissue engineering. Sci. Rep. 2017, 7, 17187. [CrossRef]

22. Park, K.M.; Lee, S.Y.; Joung, Y.K.; Na, J.S.; Lee, M.C.; Park, K.D. Thermosensitive chitosan-Pluronic hydrogel as an injectable cell delivery carrier for cartilage regeneration. Acta Biomater. 2009, 5, 1956-1965. [CrossRef]

23. Grolman, J.M.; Singh, M.; Mooney, D.J.; Eriksson, E.; Nuutila, K. Antibiotic-containing agarose hydrogel for wound and burn care. J. Burn Care Res. 2019, 40, 900-906. [CrossRef] [PubMed]

24. Kim, C.; Jeong, D.; Kim, S.; Kim, Y.; Jung, S. Cyclodextrin functionalized agarose gel with low gelling temperature for controlled drug delivery systems. Carbohydr. Polym. 2019, 222, 115011. [CrossRef] [PubMed]

25. Jain, K.; Rubin, A.L.; Asina, S.; Smith, B.; Stenzel, K. Agarose Coated Agarose Beads Containing Cancer Cells that Produce Material which Suppresses Cancer Cell Proliferation. U.S. Patent 5,888,497, 30 March 1999.

26. Guo, X.; Chen, Y.; Ji, W.; Chen, X.; Li, C.; Ge, R. Enrichment of cancer stem cells by agarose multi-well dishes and 3D spheroid culture. Cell Tissue Res. 2019, 375, 397-408. [CrossRef] [PubMed]

27. Hafezi, M.; Qin, L.; Mahmoodi, P.; Dong, G. Osmosis effect on protein sustained release of Agarose hydrogel for anti-friction performance. Tribol. Int. 2019, 132, 108-117. [CrossRef]

28. Hasan, M.L.; Padalhin, A.R.; Kim, B.; Lee, B.T. Preparation and evaluation of BCP-CSD-agarose composite microsphere for bone tissue engineering. J. Biomed. Mater. Res. Part B Appl. Biomater. 2019, 107, $2263-2272$. [CrossRef]

29. Carriel, V.; Vizcaíno-López, G.; Chato-Astrain, J.; Durand-Herrera, D.; Alaminos, M.; Campos, A.; Sánchez-Montesinos, I.; Campos, F. Scleral surgical repair through the use of nanostructured fibrin/agarose-based films in rabbits. Exp. Eye Res. 2019, 186, 107717. [CrossRef]

30. Tripathi, A.; Kumar, A. Multi-featured macroporous agarose-alginate cryogel: Synthesis and characterization for bioengineering applications. Macromol. Biosci. 2011, 11, 22-35. [CrossRef]

31. Pearl, G.S.; Check, I.J.; Hunter, R.L. Agarose electrophoresis and immunonephelometric quantitation of cerebrospinal fluid immunoglobulins: Criteria for application in the diagnosis of neurologic disease. Am. J. Clin. Pathol. 1984, 81, 575-580. [CrossRef]

32. Zheng, H.; Lang, Y.; Yu, J.; Han, Z.; Chen, B.; Wang, Y. Affinity binding of aptamers to agarose with DNA tetrahedron for removal of hepatitis B virus surface antigen. Colloids Surf. B Biointerfaces 2019, 178, 80-86. [CrossRef]

33. Shiesh, S.-C.; Ting, W.-K.; Jap, T.-S. Measurement of creatine kinase isoforms by agarose gel electrophoresis in the diagnosis of myocardial infarction. Clin. Biochem. 1992, 25, 293-301. [CrossRef]

34. Stokols, S.; Sakamoto, J.; Breckon, C.; Holt, T.; Weiss, J.; Tuszynski, M.H. Templated agarose scaffolds support linear axonal regeneration. Tissue Eng. 2006, 12, 2777-2787. [CrossRef] [PubMed]

35. Sánchez-Salcedo, S.; Nieto, A.; Vallet-Regí, M. Hydroxyapatite/ $\beta$-tricalcium phosphate/agarose macroporous scaffolds for bone tissue engineering. Chem. Eng. J. 2008, 137, 62-71. [CrossRef]

36. Miguel, S.P.; Ribeiro, M.P.; Brancal, H.; Coutinho, P.; Correia, I.J. Thermoresponsive chitosan-agarose hydrogel for skin regeneration. Carbohydr. Polym. 2014, 111, 366-373. [CrossRef] [PubMed]

37. Pettikiriarachchi, J.T.; Parish, C.L.; Shoichet, M.S.; Forsythe, J.S.; Nisbet, D.R. Biomaterials for brain tissue engineering. Aust. J. Chem. 2010, 63, 1143-1154. [CrossRef]

38. Troken, A.J.; Mao, J.J.; Marion, N.W.; Wan, L.Q.; Mow, V.C. Cartilage and Meniscus, Properties of. Encyclop. Med. Devices Instrum. 2006. [CrossRef] 
39. Hayami, T.; Pickarski, M.; Zhuo, Y.; Wesolowski, G.A.; Rodan, G.A.; Duong, L.T. Characterization of articular cartilage and subchondral bone changes in the rat anterior cruciate ligament transection and meniscectomized models of osteoarthritis. Bone 2006, 38, 234-243. [CrossRef]

40. Setayeshmehr, M.; Esfandiari, E.; Rafieinia, M.; Hashemibeni, B.; Taheri-Kafrani, A.; Samadikuchaksaraei, A.; Kaplan, D.L.; Moroni, L.; Joghataei, M.T. Hybrid and composite scaffolds based on extracellular matrices for cartilage tissue engineering. Tissue Eng. Part B Rev. 2019, 25, 202-224. [CrossRef]

41. Goldstein, A.S. Biomaterials for Cell Delivery: Vehicles in Regenerative Medicine; CRC Press: Boca Raton, FL, USA, 2018.

42. Mahato, R.I. Biomaterials for Delivery and Targeting of Proteins and Nucleic Acids; CRC Press: Boca Raton, FL, USA, 2004.

43. Kwon, H.; Paschos, N.K.; Hu, J.C.; Athanasiou, K. Articular cartilage tissue engineering: The role of signaling molecules. Cell. Mol. Life Sci. 2016, 73, 1173-1194. [CrossRef]

44. Usami, Y.; Gunawardena, A.T.; Iwamoto, M.; Enomoto-Iwamoto, M. Wnt signaling in cartilage development and diseases: Lessons from animal studies. Lab. Investig. 2015, 96, 186-196. [CrossRef]

45. Thorfve, A. Bone and Cartilage Regeneration: Wnt Signaling Pathway in Healing. Ph.D. Thesis, University of Gothenburg, Gothenburg, Sweden, 2014.

46. Santos, G.; Doty, M. Agarose from Gracilaria cylindrica. Bot. Mar. 1983, 26, 31-34. [CrossRef]

47. Zhang, Y.; Fu, X.; Duan, D.; Xu, J.; Gao, X. Preparation and characterization of agar, agarose, and agaropectin from the red alga Ahnfeltia plicata. J. Oceanol. Limnol. 2019, 37, 815-824. [CrossRef]

48. Jeon, Y.-J.; Athukorala, Y.; Lee, J.-H. Characterization of agarose product from agar using DMSO. Algae 2005, 20, 61-67. [CrossRef]

49. Din, S.S.; Chew, K.W.; Chang, Y.-K.; Show, P.L.; Phang, S.M.; Juan, J.C. Extraction of agar from Eucheuma cottonii and Gelidium amansii seaweeds with sonication pretreatment using autoclaving method. J. Oceanol. Limnol. 2019, 37, 871-880. [CrossRef]

50. Kaupp, J.A.; Weber, J.F.; Waldman, S.D. Mechanical stimulation of chondrocyte-agarose hydrogels. J. Vis. Exp. 2012, 68, 4229. [CrossRef]

51. Trivedi, T.J.; Kumar, A. Efficient extraction of agarose from red algae using ionic liquids. Green Sustain. Chem. 2014, 4, 190. [CrossRef]

52. Buskila, D.; Neumann, L.; Vaisberg, G.; Alkalay, D.; Wolfe, F. Increased rates of fibromyalgia following cervical spine injury. A controlled study of 161 cases of traumatic injury. Arthritis Rheum. 1997, 40, 446-452. [CrossRef]

53. Singh, Y.P.; Bhardwaj, N.; Mandal, B.B. Potential of agarose/silk fibroin blended hydrogel for in vitro cartilage tissue engineering. ACS Appl. Mater. Interfaces 2016, 8, 21236-21249. [CrossRef]

54. Szychlinska, M.A.; D'Amora, U.; Ravalli, S.; Ambrosio, L.; Di Rosa, M.; Musumeci, G. Functional Biomolecule Delivery Systems and Bioengineering in Cartilage Regeneration. Curr. Pharm. Biotechnol. 2019, 20, 32-46. [CrossRef]

55. Green, S. PEEK Biomaterials Handbook; Elsevier: Amsterdam, The Netherlands, 2012.

56. Anderson, J.M. Biocompatibility and bioresponse to biomaterials. In Principles of Regenerative Medicine; Elsevier: Amsterdam, The Netherlands, 2019; pp. 675-694.

57. Sefat, F.; Raja, T.I.; Zafar, M.S.; Khurshid, Z.; Najeeb, S.; Zohaib, S.; Ahmadi, E.D.; Rahmati, M.; Mozafari, M. Nanoengineered biomaterials for cartilage repair. In Nanoengineered Biomaterials for Regenerative Medicine; Elsevier: Amsterdam, The Netherlands, 2019; pp. 39-71.

58. Ulery, B.D.; Nair, L.S.; Laurencin, C.T. Biomedical applications of biodegradable polymers. J. Polym. Sci. Part B Polym. Phys. 2011, 49, 832-864. [CrossRef]

59. Nair, L.S.; Laurencin, C.T. Biodegradable polymers as biomaterials. Progress Polym. Sci. 2007, 32, 762-798. [CrossRef]

60. Kock, L.M.; Geraedts, J.; Ito, K.; Van Donkelaar, C.C. Low agarose concentration and TGF- $\beta 3$ distribute extracellular matrix in tissue-engineered cartilage. Tissue Eng. Part A 2013, 19, 1621-1631. [CrossRef]

61. Park, S.-J.; Goodman, M.B.; Pruitt, B.L. Measurement of mechanical properties of Caenorhabditis elegans with a piezoresistive microcantilever system. In Proceedings of the 3rd IEEE/EMBS Special Topic Conference on Microtechnology in Medicine and Biology, Oahu, HI, USA, 12-15 May 2005; pp. 400-403.

62. Kandadai, M.A.; Raymond, J.L.; Shaw, G.J. Comparison of electrical conductivities of various brain phantom gels: Developing a 'brain gel model'. Mater. Sci. Eng. C 2012, 32, 2664-2667. [CrossRef] [PubMed] 
63. Scionti, G.; Moral, M.; Toledano, M.; Osorio, R.; Duran, J.D.; Alaminos, M.; Campos, A.; López, M.T. Effect of the hydration on the biomechanical properties in a fibrin-agarose tissue-like model. J. Biomed. Mater. Res. Part A 2014, 102, 2573-2582. [CrossRef] [PubMed]

64. Pal, S. Mechanical properties of biological materials. In Design of Artificial Human Joints E Organs; Springer: Berlin, Germany, 2014; pp. 23-40.

65. Nguyen, B.V.; Wang, Q.G.; Kuiper, N.J.; El Haj, A.J.; Thomas, C.R.; Zhang, Z. Biomechanical properties of single chondrocytes and chondrons determined by micromanipulation and finite-element modelling. J. R. Soc. Interface 2010, 7, 1723-1733. [CrossRef] [PubMed]

66. Spedden, E.; White, J.D.; Naumova, E.N.; Kaplan, D.L.; Staii, C. Elasticity maps of living neurons measured by combined fluorescence and atomic force microscopy. Biophys. J. 2012, 103, 868-877. [CrossRef]

67. Ogneva, I.V.; Lebedev, D.V.; Shenkman, B.S. Transversal stiffness and Young's modulus of single fibers from rat soleus muscle probed by atomic force microscopy. Biophys. J. 2010, 98, 418-424. [CrossRef]

68. Collinsworth, A.M.; Zhang, S.; Kraus, W.E.; Truskey, G.A. Apparent elastic modulus and hysteresis of skeletal muscle cells throughout differentiation. Am. J. Physiol. Cell Physiol. 2002, 283, C1219-C1227. [CrossRef]

69. Saha, K.; Keung, A.J.; Irwin, E.F.; Li, Y.; Little, L.; Schaffer, D.V.; Healy, K.E. Substrate modulus directs neural stem cell behavior. Biophys. J. 2008, 95, 4426-4438. [CrossRef]

70. Chen, E.J.; Novakofski, J.; Jenkins, W.K.; O’Brien, W.D. Young's modulus measurements of soft tissues with application to elasticity imaging. IEEE Trans. Ultrason. Ferroelectr. Freq. Control 1996, 43, 191-194. [CrossRef]

71. Mauck, R.L.; Soltz, M.A.; Wang, C.C.; Wong, D.D.; Chao, P.-H.G.; Valhmu, W.B.; Hung, C.T.; Ateshian, G.A. Functional tissue engineering of articular cartilage through dynamic loading of chondrocyte-seeded agarose gels. J. Biomech. Eng. 2000, 122, 252-260. [CrossRef]

72. Hung, C.T.; Mauck, R.L.; Wang, C.C.-B.; Lima, E.G.; Ateshian, G.A. A paradigm for functional tissue engineering of articular cartilage via applied physiologic deformational loading. Ann. Biomed. Eng. 2004, 32, 35-49. [CrossRef]

73. Roach, B.L.; Nover, A.B.; Ateshian, G.A.; Hung, C.T. Agarose hydrogel characterization for regenerative medicine applications: Focus on engineering cartilage. In Biomaterials from Nature for Advanced Devices and Therapies; John Wiley \& Sons: Hoboken, NJ, USA, 2016; p. 258.

74. Lee, H.-H.; Chang, C.-C.; Shieh, M.-J.; Wang, J.-P.; Chen, Y.-T.; Young, T.-H.; Hung, S.-C. Hypoxia enhances chondrogenesis and prevents terminal differentiation through PI3K/Akt/FoxO dependent anti-apoptotic effect. Sci. Rep. 2013, 3, 1-12. [CrossRef] [PubMed]

75. Guaccio, A.; Borselli, C.; Oliviero, O.; Netti, P. Oxygen consumption of chondrocytes in agarose and collagen gels: A comparative analysis. Biomaterials 2008, 29, 1484-1493. [CrossRef]

76. Cigan, A.D.; Roach, B.L.; Nims, R.J.; Tan, A.R.; Albro, M.B.; Stoker, A.M.; Cook, J.L.; Vunjak-Novakovic, G.; Hung, C.T.; Ateshian, G.A. High seeding density of human chondrocytes in agarose produces tissue-engineered cartilage approaching native mechanical and biochemical properties. J. Biomech. 2016, 49, 1909-1917. [CrossRef]

77. Selmi, T.A.S.; Verdonk, P.; Chambat, P.; Dubrana, F.; Potel, J.-F.; Barnouin, L.; Neyret, P. Autologous chondrocyte implantation in a novel alginate-agarose hydrogel: Outcome at two years. J. Bone Jt. Surg. Br. Vol. 2008, 90, 597-604. [CrossRef] [PubMed]

78. Gu, W.; Yao, H.; Huang, C.-Y.; Cheung, H.S. New insight into deformation-dependent hydraulic permeability of gels and cartilage, and dynamic behavior of agarose gels in confined compression. J. Biomech. 2003, 36, 593-598. [CrossRef]

79. Yin, Z.; Yang, X.; Jiang, Y.; Xing, L.; Xu, Y.; Lu, Y.; Ding, P.; Ma, J.; Xu, Y.; Gui, J. Platelet-rich plasma combined with agarose as a bioactive scaffold to enhance cartilage repair: An in vitro study. J. Biomater. Appl. 2014, 28, 1039-1050. [CrossRef] [PubMed]

80. Yin, N.; Stilwell, M.D.; Santos, T.M.; Wang, H.; Weibel, D.B. Agarose particle-templated porous bacterial cellulose and its application in cartilage growth in vitro. Acta Biomater. 2015, 12, 129-138. [CrossRef] [PubMed]

81. DeKosky, B.J.; Dormer, N.H.; Ingavle, G.C.; Roatch, C.H.; Lomakin, J.; Detamore, M.S.; Gehrke, S.H. Hierarchically designed agarose and poly (ethylene glycol) interpenetrating network hydrogels for cartilage tissue engineering. Tissue Eng. Part C Methods 2010, 16, 1533-1542. [CrossRef] [PubMed] 
82. Bonhome-Espinosa, A.B.; Campos, F.; Durand-Herrera, D.; Sánchez-López, J.D.; Schaub, S.; Durán, J.D.; Lopez-Lopez, M.T.; Carriel, V. In vitro characterization of a novel magnetic fibrin-agarose hydrogel for cartilage tissue engineering. J. Mech. Behav. Biomed. Mater. 2020, 104, 103619. [CrossRef] [PubMed]

83. Yang, F.; Zhang, Y.; Liu, B.; Cao, M.; Yang, J.; Tian, F.; Yang, P.; Qin, K.; Zhao, D. Basic fibroblast growth factor and agarose gel promote the ability of immune privilege of allogeneic cartilage transplantation in rats. J. Orthop. Transl. 2019. [CrossRef]

(C) 2020 by the authors. Licensee MDPI, Basel, Switzerland. This article is an open access article distributed under the terms and conditions of the Creative Commons Attribution (CC BY) license (http://creativecommons.org/licenses/by/4.0/). 